Arctoa (2001) 10: 207-218

\title{
NOTES ON LOPHOZIA III. SOME TAXONOMIC PROBLEMS IN LOPHOZIA SECT. LOPHOZIA
}

\section{ЗАПИСКИ ПО РОДУ LOPНОZIA III. НЕКОТОРЫЕ ТАКСОНОМИЧЕСКИЕ ПРОБЛЕМЫ В ГРУППЕ LOHPOZIA SECT. LOPHOZIA}

\author{
VADIM A. BAKALIN ${ }^{1}$ \\ ВАДИМ АНДРЕЕВИЧ БАКАЛИН ${ }^{1}$
}

Abstract

\begin{abstract}
Analyses of miscellaneous materials of green-gemmous Lophozias have shown: (1) L. silvicola is a distinct species from L.ventricosa. (2) L. iremelensis is synonymous with $L$. ventricosa and treatment of the former as conspecific with L. wenzelii is erroneous. (3) Jungermannia groenlandica is a distinct variety of L. wenzelii. (4) The separating of the sect. Guttulatae is unfounded because of absence of constant defining features from sect. Lophozia. So, sect. Guttulatae should be rejected. (5) L. silvicoloides seems to be a more or less common species of East Siberia and Far East with a few disjunctions in Europe. The species is close on the one hand to L.silvicola and on the other hand to L. ascendens. Two new combinations are proposed: Lophozia ventricosa var. guttulata (Lindb. et H. W. Arnell) Bakalin comb. nov. and Lophozia wenzelii var. groenlandica (Nees) Bakalin comb. n. The key for identification of Holarctic's green-gemmous Lophozias is presented.
\end{abstract}

Резюме

На основании изучения разнообразного материала по видам Lophozia с зелеными выводковыми почками показано, что: (1) L. silvicola является ясно отличимым от $L$. ventricosa видом. (2) Синонимом L. ventricosa является L. iremelensis, отождествление которой с L. wenzelii неверно. (3) Таксон, описанный под именем Jungermannia groenlandica, должен рассматриваться в качестве разновидности L. wenzelii. (4) Выделение секции Guttulatae необоснованно, поскольку не имеется ни одного принципиально отличного признака от секции Lophozia. (5) L. silvicoloides довольно широко распространена на территории Восточной Сибири и Дальнего Востока и имеет отдельные дизъюнкции в Европе. Этот вид сближается, с одной стороны, с $L$. silvicola, а с другой с L. ascendens. Предлагаются две новых комбинации: Lophozia ventricosa var. guttulata (Lindb. et H. W. Arnell) Bakalin comb. nov. и Lophozia wenzelii var. groenlandica (Nees) Bakalin comb. n. Прводится ключ для определения зеленопочковых видов рода Lophozia.

Admittedly the genus Lophozia represents one in the most polymorphous and difficult genera of hepatics in Holarctic. Further, its division into species is a very intricate question and the specific limits were treated variously not only by different hepaticologists, but also by one specialist during one or two decades (compare Schljakov, 1969 and 1980). I believe that green-gemmous Lophozias represent the biggest problem in the genus, but probably the troubles are more obvious because the species are more common than other ones.

After critical study of collections of this genus in BM, KYO, LE, MHA, MUB, MW, NMW,
PMAE, PZV, STR, SYKO, and UPS I came to the following conclusions on some parts of this group. Problems around $L$. savicziae were discussed by Bakalin (2000), and the complex L. wenzelii-schusteriana will be discussed in a separate article.

\section{L. SILVICOLA -- L. VENTRICOSA PROBLEM}

In the recent publications (Paton, 1999; Grolle and Long, 2000) L. longiflora (Nees) Schiffn. is usually separated from L. ventricosa (Dicks.) Dum. However, the latter species is treated very broadly as including phases with both biconcentric oilbodies and nonbiconcentric ones. Paton (1999) mentioned three main distinguishing features: L. longiflora is supposed to differ

\footnotetext{
1 - Россия 184236, Мурманская обл., Кировск-6, Полярно-Альпийский ботанический сад-институт КНЦ РАН Polar-Alpine Botanical Garden of Kola Sci. Center of Russian Academy of Sciences, Kirovsk-6, Murmansk Province 184236 Russia; e-mail: v_bak@aprec.ru
} 


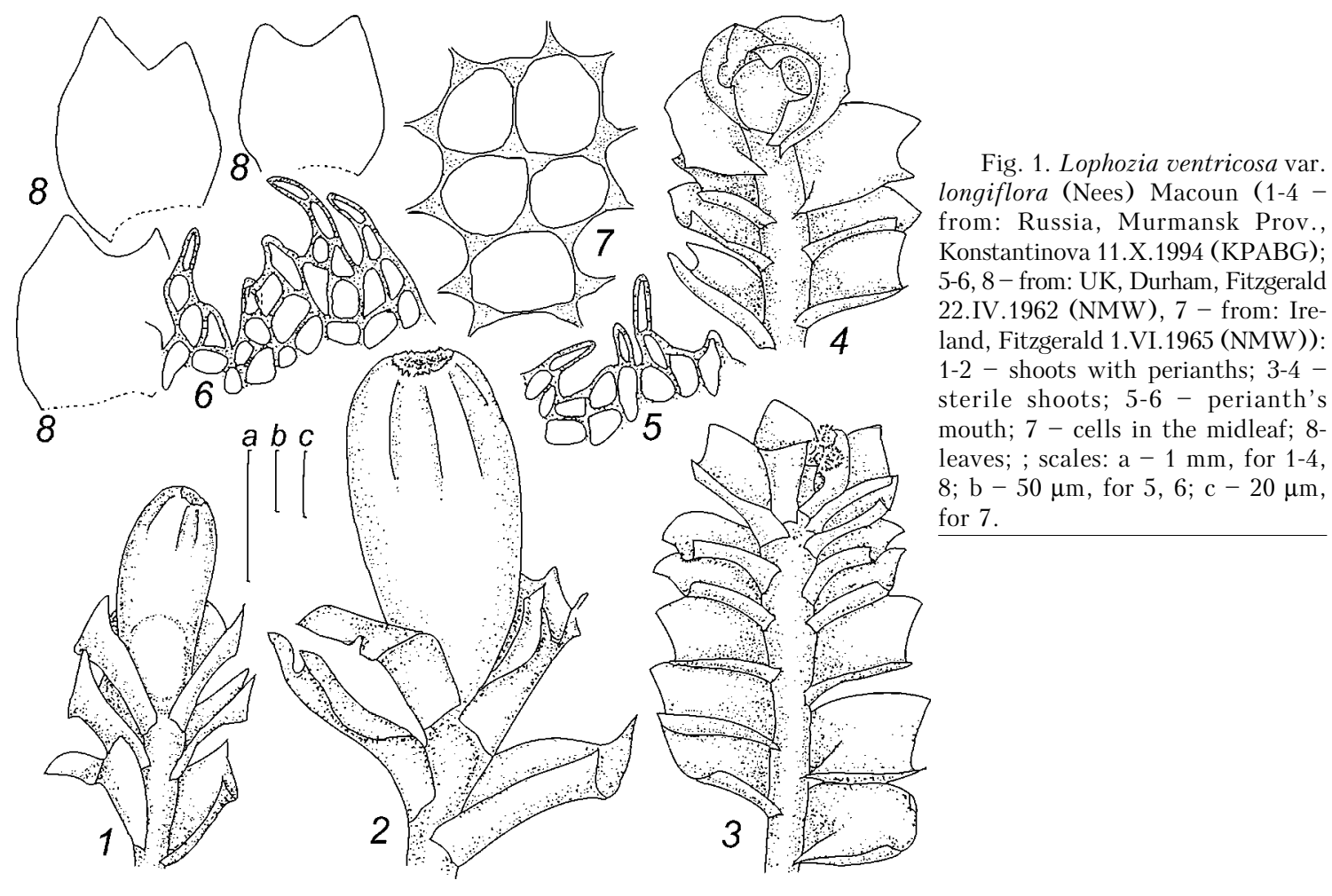

from $L$. ventricosa sensu Paton by its ciliate perianth, large leaf trigones and almost constant occurrence on decaying logs. These differences seem very critical to me. $L$. ventricosa sensu Paton (according to Paton's conclusion, 1.c.) can develop a dentate-ciliate perianth, sometimes large and convex trigones and may occur on rotting wood. I cannot agree with the usage of these characters (cf. Schljakov, 1980). Separating of L. longiflora seems to be incorrect if the "nonbiconcentric" phase in $L$. ventricosa is retained. Since Grolle and Long (2000) neotypified $L$. ventricosa by plants with nonbiconcentric oilbodies, L. longiflora can not be separated from $L$. ventricosa at the species level because of the absence of any constant differences. So, L. longiflora is treated here as a variety of $L$. ventricosa. In this case, plants with biconcentric oilbodies should be named $L$. silvicola.

The differences between L. ventricosa (Fig. 1) and L. silvicola (Fig. 2) are shown in Table I. Further, very characteristic of $L$. silvicola are trilobate leaves with shallowly crescentic sinuses, frequently occurring in all modifications of this species. Similar leaves are observed in
L. ascendens (Warnst.) Schust. and $L$. longidens (Lindb.) Macoun. Shape of trigones is a valuable feature according to Schljakov (1980). Thus $L$. ventricosa versus $L$. silvicola has peculiarly curved cell lumens which were not observed in mod. pachyderma of the latter species (cf. figs. 1.7. and 3.3.).

Additional distinguishing features that can be used are (1) size of trigones $-L$. ventricosa has moderately to large convex trigones as a rule, in comparison to the almost always concave ones of L. silvicola; (2) L. silvicola never develops cilia of 3-4 cells on perianth's mouth, that are characteristic for $L$. ventricosa, and its var. guttulata (Lindb. et H.W. Arnell) Baka$\operatorname{lin}^{1}$, especially.

One of varieties of $L$. ventricosa is var. confusa Schust. It includes mainly lax-leaved plants of the species (Fig. 4.). The instability of the armature of the perianth mouth and the leaf shape suggest that this variety appears to be an ancient little-specialized satellite of its species, more or less close to L. silvicola, L. wenzelii

\footnotetext{
1 - Lophozia ventricosa var. guttulata (Lindb. and H.W. Arnell) Bakalin comb. nov. -- Basionim: Jungermannia guttulata Lindb. et H.W. Arnell In: Musci As. Bor.: 51
} 
Fig. 2. Lophozia silvicola Buch (from: Russia, Karelia, Bakalin 15.VII.1998 (KPABG): 1-2 sterile shoots; 3 - leaves; scale a $-1 \mathrm{~mm}$, for $1-3$.

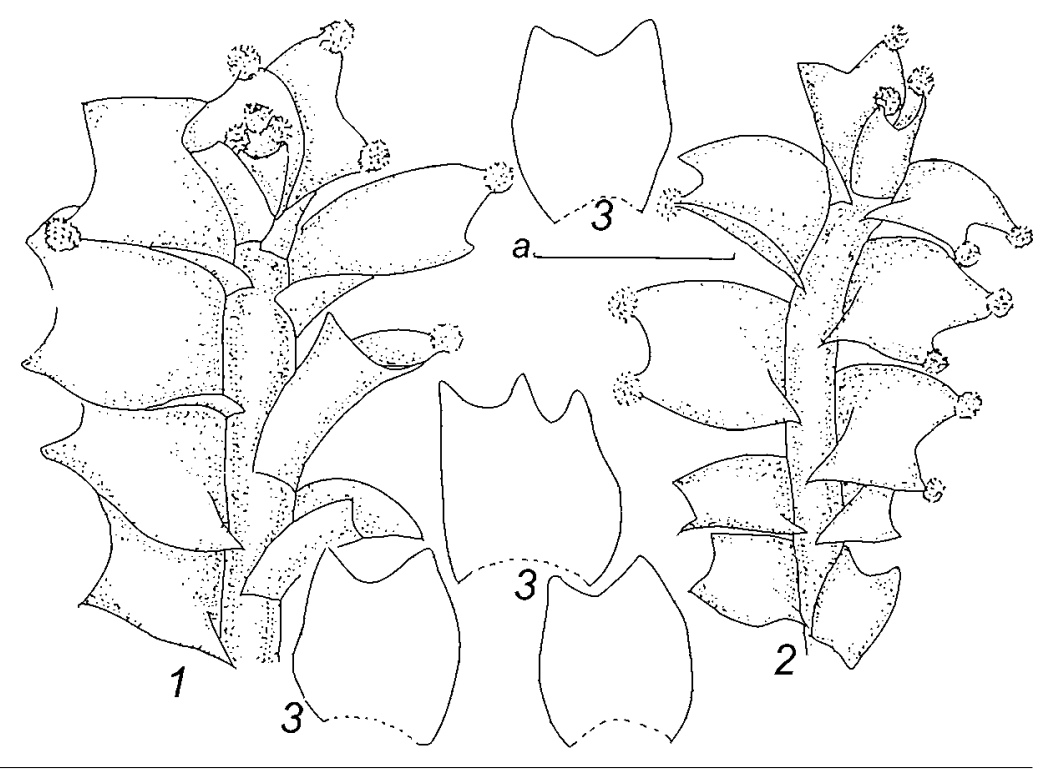

and L. schusteriana. The lax-leaved phenotypes of var. confusa may be confused with $L$. silvicola, and L. wenzelii, probably. The additional distinguishing features from L. silvicola are: (1) characteristic "capitate" apex of shoots, (2) width of cells in the midleaf attaining 22-26 $\mu \mathrm{m}$ in lax-leaved shoots of $L$. ventricosa versus 25-30 $\mu \mathrm{m}$, (3) the absence of trilobate leaves with crescentic sinuses. L. wenzelii s.str. easily differs from var. confusa by its concave to cupped leaves, narrow, mainly semilunate sinus and by specific brown-yellowish pigmentation without reddish coloration. For the differentiation of var. confusa from L. wenzelii var. groenlandica see below.

As many other polymorphous species L. silvicola can develop somewhat anomalous forms which create confusion. I observed L silvicola with "funnelate" base of the leaves, but other distinguishing features (Table 1) were kept. Leaves of L. silvicola mod. colorata-pachyder$m a$ (Fig. 3.) loose their typical appearance frequently, and some are the widest below the middle. However, the characteristic trilobate leaves with shallowly crescentic sinuses can be observed in those forms, even. Sometimes, leaves of mod. pachyderma-colorata look like those of L. savicziae Schljak., also by large leaf-cells (the width of them can attain $30 \mu \mathrm{m}$ in the midleaf), but L. silvicola may be easily recognized by leaves decurved from the stem versus cupped leaves of mod. pachyderma of L. savicziae (cf. Bakalin, 2000).

\section{WHAT IS LOPHOZIA IREMELENSIS SCHLJAK.?}

Lophozia iremelensis was described on the basis of three specimens from the South Ural (Schljakov, 1998b). According to the original

Table I. Comparison of L. silvicola and L. ventricosa

\section{Features}

structure of oil bodies

shape of leaves

gemmae distribution

bracteole sinus of the bracts perianth's teeth

\section{L. silvicola}

\section{biconcentric}

explanate, subhorizontally inserted, almost never form a "funnel" with the stem, leaves decurved from the stem

gemmae are clustered on the ends of the lobes and those clusters are descended down from the apex mainly lanceolate not decurved from the perianth apical cell of teeth 1.5-2.5 as long as wide

\section{L. ventricosa}

non-biconcentric

somewhat slightly conduplicate, frequently subtransversely orientated, always with a funnel at the base, lobes directed to the apex of the stem gemmae early deciduous and concentrated merely on the apex of the shoots

mainly bilobate decurved from the perianth apical cell of teeth $2.5-4$ as long as wide 

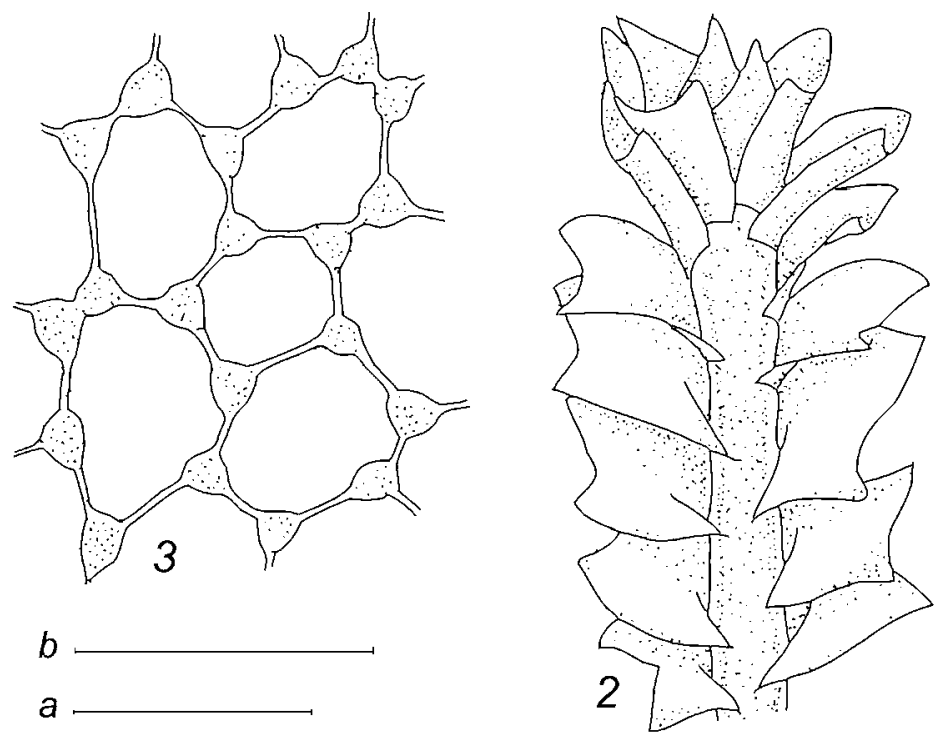

Fig. 3. Lophozia silvicola Buch mod. pachyderma-colorata (from: UK, Wales, Glamorgan, Fitzgerald, IV.1962 (NMW)): 1 - leaves; 2 - sterile shoot; 3 - cells in the midleaf; scales: a $-1 \mathrm{~mm}$, for $1-2$; $\mathrm{b}-50 \mu \mathrm{m}$, for 3 .
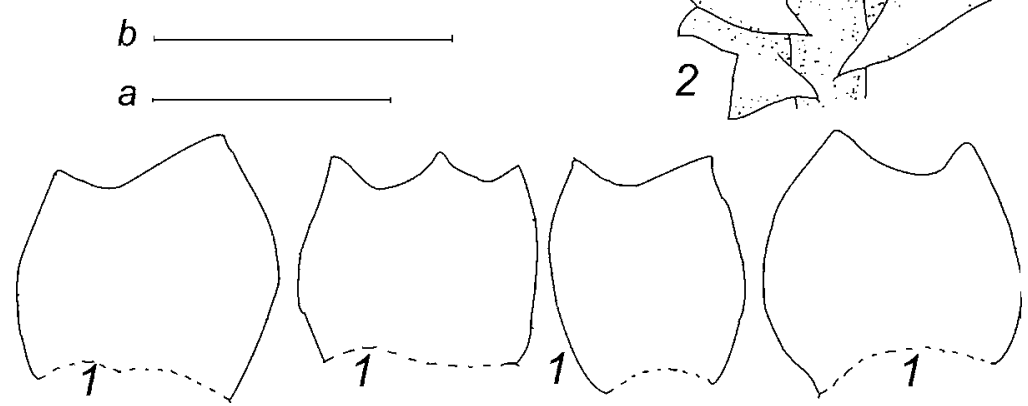

descriptions it differs from other taxa of $\mathrm{LO}^{-}$ phozia in "almost explanate leaves with obtuse lobes". These features are almost impossible to measure so I was confused as to the status of this taxon.

Subsequently, Grolle and Long (2000) treated $L$. iremelensis as synonymous with $L$. wenzelii on the basis "Vana, pers. comm.". These authors stated that Vana had studied authentic material of $L$. iremelensis. This is not quite correct. Really, as I was informed by curators of LE and MHA, where type specimens are deposited, Vana studied duplicates, which were extracted from samples by Dr. Ignatov and were sent him for identification. Then Vana determined them as L. longiflora. This happened some years before Schljakov studied the collection. So, the author of L. iremelensis did not see the specimens examined by Vana and I cannot be assured that "duplicate" of the latter contained the same species as in the envelope with the inscription: "Lophozia iremelensis. Holotypus".

The analysis of authentic specimens of $L$. iremelensis (borrowed from LE and MHA) confirms its identity as L. ventricosa. The ho- lotype and the isotype contain only lax-leaved plants of the latter species with characteristic features listed in Table 1 (Fig.5.). However, the paratype from the Mt. Bolshoi Irmel' was separated by Schljakov into two microscopic parts which contain only L. sudetica (Hueb.) Grolle with the characteristic rusty-brown pigmentation. One part contains antheridial shoots only (MHA), but the other contains sterile plants with numerous rusty-brown gemmae (LE). On the basis of the holotype I consider L. iremelensis to be synonymous with $L$. ventricosa .

Lophozia ventricosa (Dicks.) Dum. Recuel Observ. Jungerm.: 17. 1835. - Lophozia iremelensis Schljak. Novosti Sist. Nizsh. Rast. 32: 180. 1998. syn. nov.

\section{WHAT IS JUNGERMANNIA GROENLANDICA NEES EX GOTTSCHE, NEES ET LINDENBERG?}

Since its description (Gottsche et al.,1844) Jungermannia groenlandica (= Lophozia groenlandica (Nees) Macoun) has been variously interpreted. Stephani (1902) considered it as a distinct species, and placed it to genus Sphenolobus. But Müller (1954) believed $J$. groenlandica only to be a peculiar form of $L$. wenzelii. Further, Damsholt (1994) lectotypi- 
Fig. 4. Lophozia ventricosa var. confusa Schust. (from: Russia, Karelia, Bakalin 16.VII.1998 (KPABG)): 1-2 - sterile shoots; 3 - leaves; scale a $-1 \mathrm{~mm}$, for 1-3.

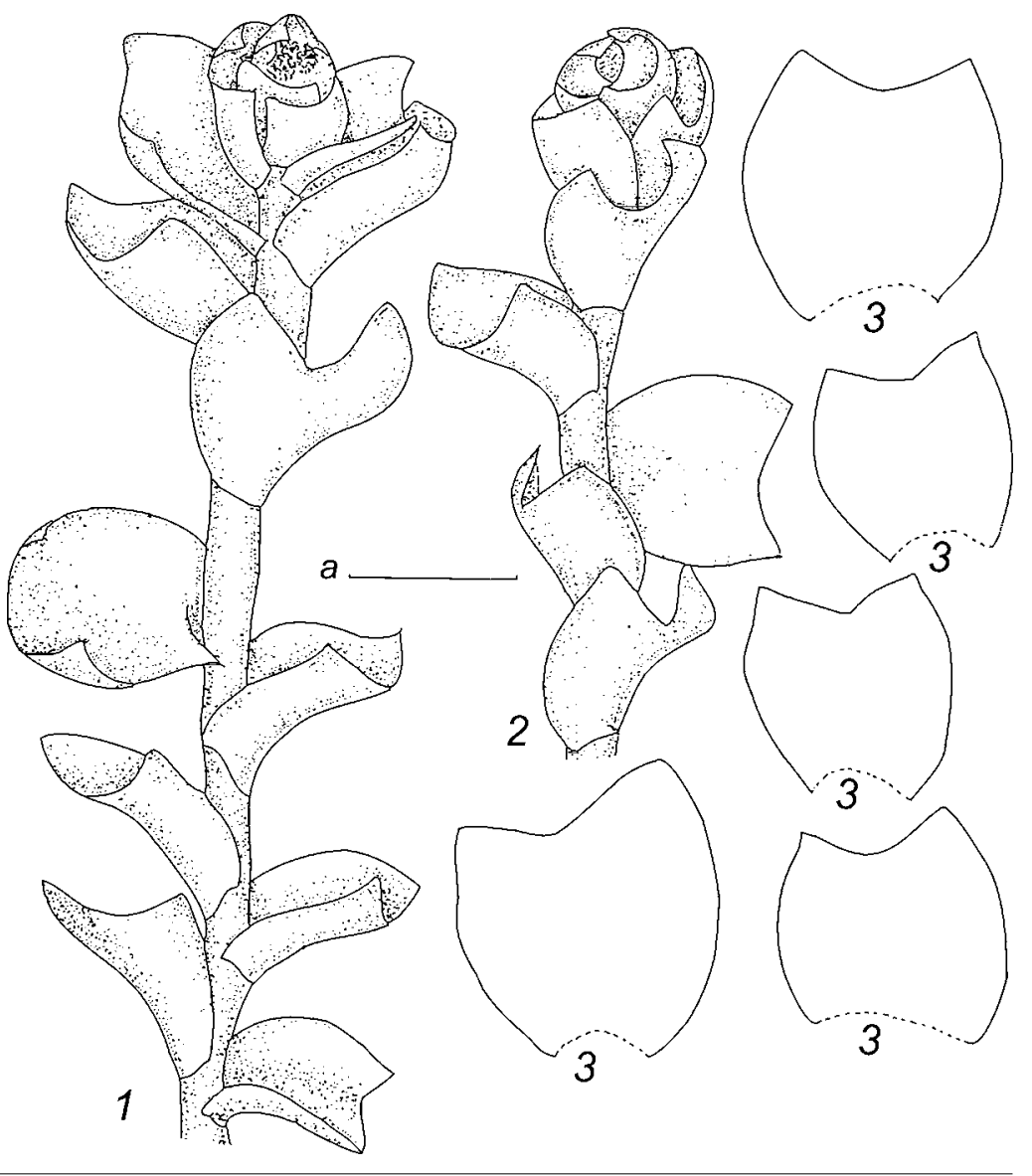

fied this species and treated it as a synonym of L. wenzelii. Finally, Schljakov (1998a) stated that Damsholt's conclusion was erroneous, and retained specific level for the taxon. However, according to Schljakov (l.c.), Damsholt's lectotypification is correct.

My investigation of the genus discusses this problem again.

Damsholt (1994) described the history of the taxon in detail, convincingly substantiating the lectotype, and his lectotypification appears to be correct. However, Damsholt's description of lectotype plants is very brief, and he does not give convincing support for the main result of his work, i.e. synonymy of J. groenlandica to L. wenzelii. Damsholt's description of the lectotype plants is as follows: "The stem is purplish black ventrally, with extensive mycorrhizae in the ventral half or more. The leaves are 2lobed, with mostly blunt lobes (only occasional with a 3-lobed leaf), somewhat concave, with shallow lunate sinuses. The gemmae are light- green (brownish now by age), 2- celled, angular to stellate. The female bracts are 2-3-lobed; bracteole lanceolate, connate with one bract. The perianth is long exserted, plicate in the upper third, contracted to the mouth; the perianth mouth has a few 1-celled teeth". So, this description is a very formal one and can be referred also to L. savicziae Schljak., L. schusteriana Schljak. and L. groenlandica sensu Schljakov. I estimate, of course, that the brief description is a result of the microscopic size of the specimen and its critical condition, but these reasons do not free us from the necessity to decide the status of taxon.

Thetype description (Gottsche and al.,1844), earlier figures and other description based on type material may be more informative then a study of a microscopic, half-destroyed lectotype.

$J$. groenlandica was described by Nees (Gottsche et al., 1844) as "Jungermannia amphigastriis nullis, caule adscendente simplici dichotomove ventre parce radiculoso, foliis 


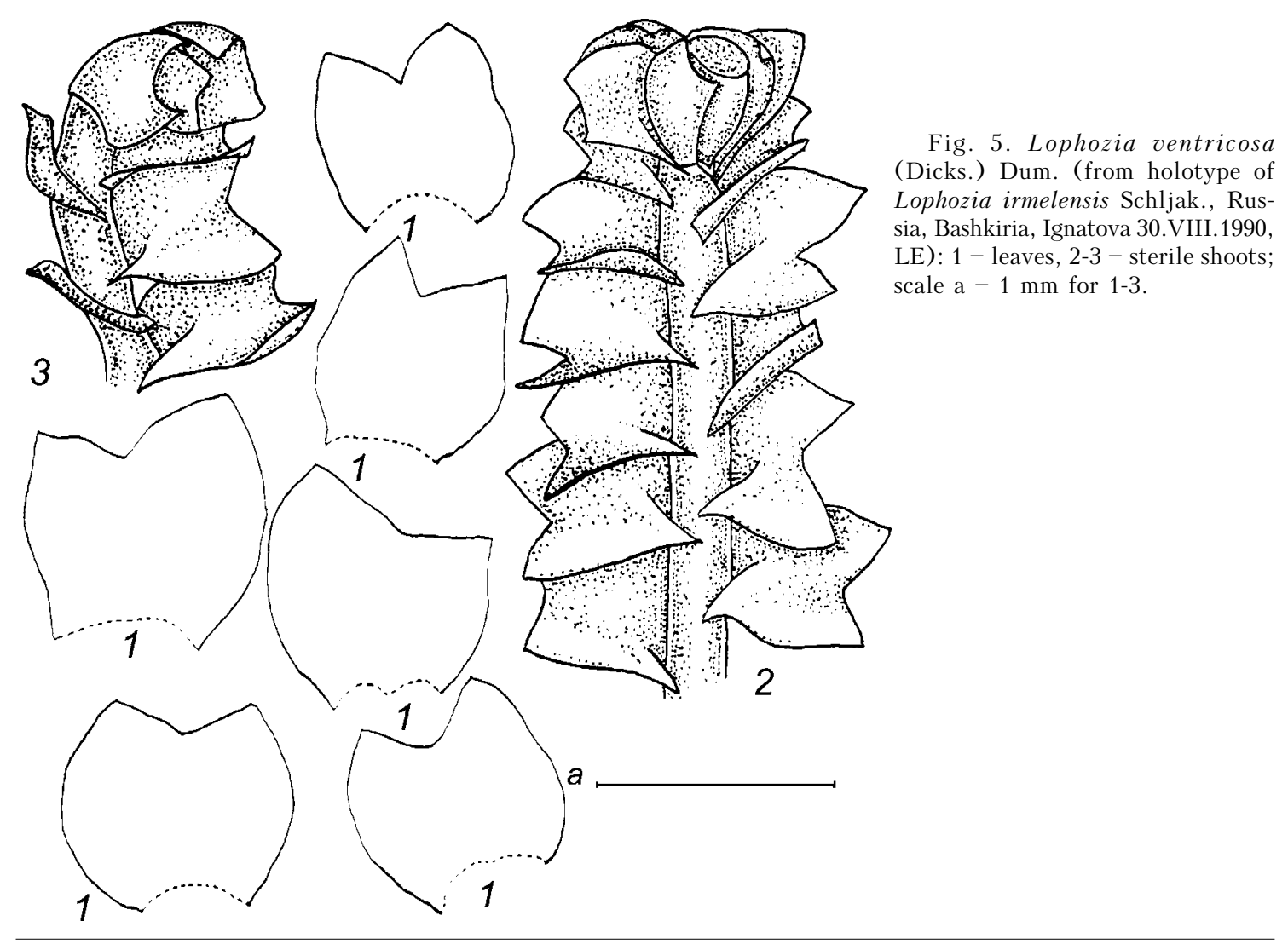

semiverticalibus in dorso contiguis molibus decurentibusque suborbiculatis convoluto-concavis subrepandis margine ventrali arcuato sinu obtuso bi-tridentatis dentibus obtusis acutisve inflexis inaequalibus, involucri foliis basi connatis trifidis erectis, perianthio obovato angulato ore 4-5-fido denticulato".

Jungermannia without amphigastria, stem ascending, simple dichotomous branched, ventral segment rhizoidal, leaves obliquely inserted, in dorsal part slightly decurrent, suborbiculate, convolute-concave, slightly decurved, ventral margin arched, bi- to trilobate, sinus and lobes obtuse, inflexed, unequal, bracts connected at base, trilobate, erect; perianth obovate, angulate, mouth 4-5-lobate, dentate". Habitat in Greenland, densely caespitose, among Jungermannia minuta Schreb. (Sphenolobus minutus) in tufts, with capsules. (Trans. from original).

Müller (1954) studied authentic material of the taxon and considered it a peculiar form of L. wenzelii differing from the latter by: (1) rotundate leaves directed to the apex, (2) brownish cell walls in the lobes.

The figure of $J$. groenlandica in "Flora Danica” (Steenstup \& Lange, 1858) is especially interesting, because it was depicted by Gottsche on the basis of authentic specimens. In the fig- ure one can see creeping to slightly ascending shoots with sub-imbricate, partly trilobate leaves, with sinus from semilunate to $\gamma$-shaped, the width of the leaves exceeding their length.

Further, Prof. Konstantinova kindly proved me a description and figures made by herself in 1996 from the lectotype. "Type specimens of $J$. groenlandica is microscopic and was repeatedly soaked and very old, so to determine of original pigmentation of plants seems to be impossible. Consequently, we limited features of the leaves only, those somewhat polymorphous, bi-, more rare trilobate, rotundate-quadrangulare, the widest below the midleaf, slightly oblique inserted, sinus semilunate to obtuse, cells in the midleaf attain $22-25 \mu \mathrm{m}$ in width, with moderate to gibbous trigones".

Some traits placed in the above description are somewhat suspicious for the typical $L$. wenzelii (cf. Schuster, 1969; Schljakov, 1980). These features are: (1) polymorphous sinus, (2) sometimes trilobate leaves, (3) sometimes large convex trigones, (4) habitat in "Jungermannia minuta". I studied about 300 specimens identi- 
Fig. 6. Lophozia wenzelii (Nees) Steph. var. groenlandica (Nees) Bakalin (from: Russia, Murmansk Prov., Konstantinova 15.VI.1996 (KPABG)): 1 - perianthous shoot; 2-3 - sterile shoots; 4-6 - perianth's mouth; 7 leaves; scales: a $-1 \mathrm{~mm}$, for $1-3,7$; b$50 \mu \mathrm{m}$, for $4-6$.

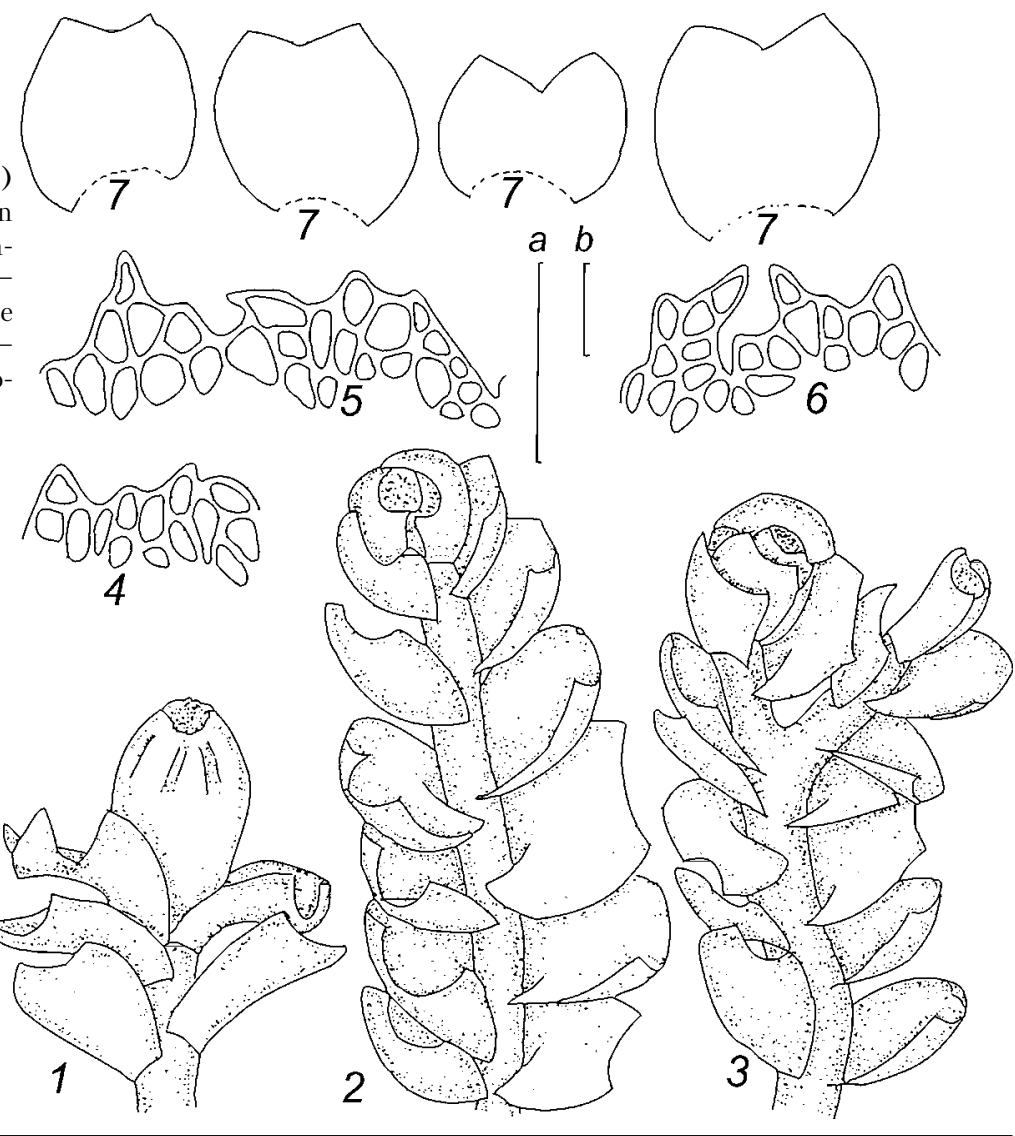

fied as L. groenlandica, L. wenzelii, and $L$. rufescens Schljak. from LE, PZV, MHA, MW, SYKO and KPABG for the purpose of clearing up the status of $J$. groenlandica. As it turned out, plants conspecific with the lectotype of the taxon have some peculiar features, but should be included in the limits of $L$. wenzelii's variability. I treat them as a distinct taxon in the variety level: Lophozia wenzelii var. groenlandica (Nees) Bakalin comb. et stat. nov. (Basionym: Jungermannia groenlandica Nees in G., L. et N., Synopsis Hepaticarum, 1844, p. 114.) It is distinguished from var. wenzelii by the following features:

1. A sinus descending to $1 / 3$ of leaf length vs. $1 / 7-1 / 5$.

2. Sinus is extraordinarily polymorphous: U, V-, $\gamma$-shaped and semilunate, vs. shallowly crescentic.

3. Trigones are distinct, often bulging, vs. concave.

4. Ventral segment of the stem often larger, to $4-5$ cells wide vs. 2-3.
5. Mouth of perianth frequently ciliate (with cilia of 2(3) cells), vs. lobate.

This combination of features seems to be result of insufficient humidity. The description of a variety follows (Fig. 6.):

Usually mesophytic, over boggy patches, more often on moist sandy or clayey soil, prostrate with obscurely ascending apices. Shoots brownyellow-greenish to blackish-brown, mostly 0,5 $1.2 \mathrm{~mm}$ broad, $0.5-3.0 \mathrm{~cm}$ long, the stems 200$500 \mu \mathrm{m}$ broad. Stems brownish, rarely greenyellowish-brown, to brown, rarely red-brown or purple-brown in ventral parts, with numerous colourless rhizoids which may be reddish or reddish-brown at base. Leaves yellow-brownish or (seldom, in shady places only) green, in distal part and base usually rather brown, obliquely to subtransversely inserted, mostly rather dense, subvertically oriented and cupped or saucershaped with the concavity turned toward stem apex, broadly orbicular to ovate, with both margins rather strongly arched, widest near, slightly above or (oftener) typically below the 
Table 2. A comparison of L. ventricosa var. confusa Schust. and L. wenzelii var. groenlandica (Nees) Bakalin

Feature

leaf base

leaf shape

direction of lobes

perianth mouth

perianth's teeth

gemmae

width of ventral segment
pigmentation of shoot

\section{L. ventricosa var. confusa}

funnelate

slightly conduplicate, asymmetrical

lobes divergent, the distance between ends of lobes ca. 0.7-0.9 of the leaf width

longidentate to ciliate with teeth of 2-4 cells

apical cell of teeth $2.5-4$ as long as wide mainly triangular to quadrate

1-2(3) cells

green to green-brown, frequently greenbrown-reddish, especially on well

insolated places

\section{L. wenzelii var. groenlandica} non-funnelate

more or less concave to capped, symmetrical lobes not divergent, the distance between ends of lobes ca. $0.5-0.7$ of the leaf width

obtuse lobulate to crenulate

apical cell of teeth 1.5-2.5 as long as wide mainly quadrangular to pentagonal 2-5 cells

brown-yellow-greenish to blackish-brown middle, width:length ca. 0,9-1,2:1,0; the incurved and usually equal lobes broadly triangular and mostly blunt to obtuse, the sinus Vor 5 -shaped with width ca.0,4-0,7 of leaf width and descending to $0,2-0,4$ of leaf length. No underleaves. Cells with more or less thin walls and distinct moderately bulging trigones to strongly collenchymatous; median cells 2227(30) x 24-30(35) $\mu \mathrm{m}$; cuticle smooth; oilbodies 4-12(17) per cell, mostly small, 3.0-4.5 x 4.0-6.0 $\mu \mathrm{m}$, some spherical and 3.5-5.0 $\mu \mathrm{m}$, uniformly finely granulate, never biconcentric. Gemmae pale green to colourless, when immature rarely slightly brownish, when gemmi parous on brown border of leaf; mostly 2-celled, weakly polygonal to pentagonal, rarely quadrate, $19-25 \times 20-25 \mu \mathrm{m}$.

Dioecious. Gynoecia with bracts more or less obovate, usually 2-3 lobed, one of those connected with two-lobed or unlobed bracteole, lobes triangular, bluntly rounded to blunt to acute, entire-margined. Perianth obpyriform, deeply plicate, at least above, mouth shallowly plurilobate, with small, almost uniformly 1--2 celled teeth.

During the study of miscellaneous specimens identified as L. groenlandica by Schljakov it turned out that his concept of L. groenlandica includes both $L$. wenzelii var. groenlandica and L. ventricosa var. confusa. As I wrote above, var. confusa is a primitive member of $L$. ventricosa s.l. and I estimate that it is the closest to $L$. wenzelii in the $L$. silvicola-ventricosa group. Indeed, current confusion of L. wenzelii with L. ventricosa (or L. longiflora), noted by many writers, e.g. Paton, 1999, Schljakov, 1980, etc. is based on the identification of var. confusa as L. wenzelii s.1. Defining features of the two taxa are in Table 2.

IV. ON THE SECTION GuttulataE SCHLJAK. In 1974 Schljakov described a new section Lophozia sect. Guttulatae including L. longiflora and L. ascendens. The main uniting features appear to be as follows (Schljakov, 1974, 1980): (1) the base of the leaf clinging the stem infundibularly, (2) cells of the leaf build into longitudinal rows directed to the sinus, (3) cells of the leaf with large or sub-large trigones, (4) margins of the sinus of the bracts inflected from the perianth.

Grolle (1983), Grolle and Long (2000), and some other authors accepted the section. However, in my opinion, the separating of the section appears to be unfounded. My arguments are follows: (1) sinus of the bracts is inflected in L. ventricosa var. longiflora (Nees) Macoun, but can be more or less explanate in var. guttulata or undulate in var. confusa; besides, $L$. ascendens almost always has explanate sinus; (2) large trigones seem to be a result of habits, so, in shady and moist places (where both species are rarer, indeed) mods. mesoderma and leptoderma can be observed, besides, the little or moderate trigones are usual in $L$. ventricosa var. confusa; (3) the direction of the cell rows (a) on the one hand, seems to be an unstable feature, because it is possible to observe any variants of those rows in a single specimen (b) on the other hand, longitudinal rows towards the sinus can be observed in the every sections recognised by Schljakov (cf. Schljakov, 1980b); (4) funnelate base of the leaf can be observed 
Fig. 7. Lophozia silvicoloides Kitag. (1-2, 4 - from Japan, Honshu, Kitagawa 14.VIII.1964 (KYO, holotype); 3, 5-6 - from Russia, Primorsky Territory, Gambaryan 1993 (KPABG)): 1 - perianthous shoot; 2 - bracts and bracteole; 3 cells in the midleaf; 4 - sterile shoot; 5 - leaves; 6 - perianth's mouth; scales: $\mathrm{a}-50 \mu \mathrm{m}$, for $6, \mathrm{~b}-50 \mu \mathrm{m}$, for $3, \mathrm{c}-1 \mathrm{~mm}$, for $1-2,4-5$.

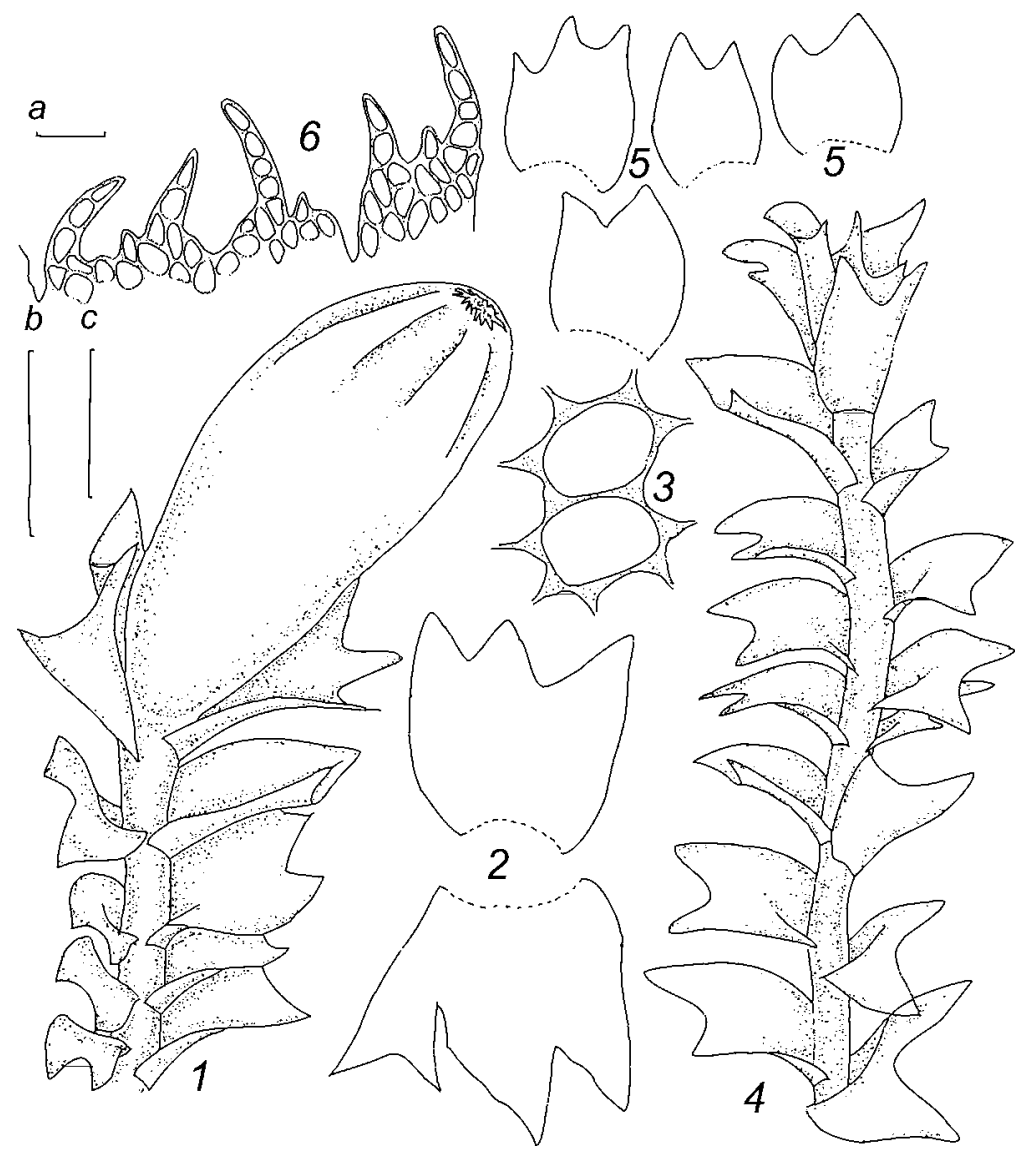

almost always in $L$. ventricosa, on the contrary, L. ascendens develops funnelate base in mod. leptoderma only, on the other hand sometimes the same leaf-base can be observed in $L$. silvicola (see above).

Therefore, my conclusion is that sect. Guttulatae can not be segregated from sect. Lophozia.

V. ON THE L. SILVICOLOIDES N. KiTAG.

Lophozia silvicoloides is a little-known species reported from only a few localities of Japan and the Northern part of the Kolyma Nagor'ye in Russia (Kitagawa, 1965; Schljakov, 1982). However, the study of the miscellaneous herbarium materials has revealed that this species seems to be more or less common in East Siberia and Russian Far East, and has rare disjunction in Europe.

Lophozia silvicoloides (Fig. 7.) is close to L. silvicola in its narrow explanate leaves and biconcentric oilbodies on the one hand and on the other hand to L. ascendens mod. leptoder$m a$ in its lacinate-dentate perianth mouth and the funnelate leaf base. According to the original description and my data L. silvicoloides almost always develops perianths. So, to separate it from $L$. ventricosa is very easy ${ }^{1}$. A more difficult problem is the relationship of $L$. silvicoloides and L. ascendens mod. leptoderma and (especially) mod. prostrata. Creeping forms of the latter occur very seldom in $\mathrm{Eu}-$ rope, but they are more common in the South of Russian Far East. These forms differ from L. silvicoloides in: (1) nonbiconcentric oilbodies, (2) explanate leaves with obtuse lobes, (3) peculiar straw-greenish pigmentation of the shoots, and (4) coloration of the ventral segment of the stem, which is clearly brownish in creeping shoots, but it never acquires the red-purplish pigmentation that is characteristic of L. silvicoloides.

1 - Besides the armature of the perianth mouth in $L$. silvicoloides the leaves are more strongly secund dorsally and the leaf cells are somewhat larger (the cells 27-40 $\mu \mathrm{m}$ near the leaf apices, in $L$. ventricos $a$ - to $30 \mu \mathrm{m})$. 


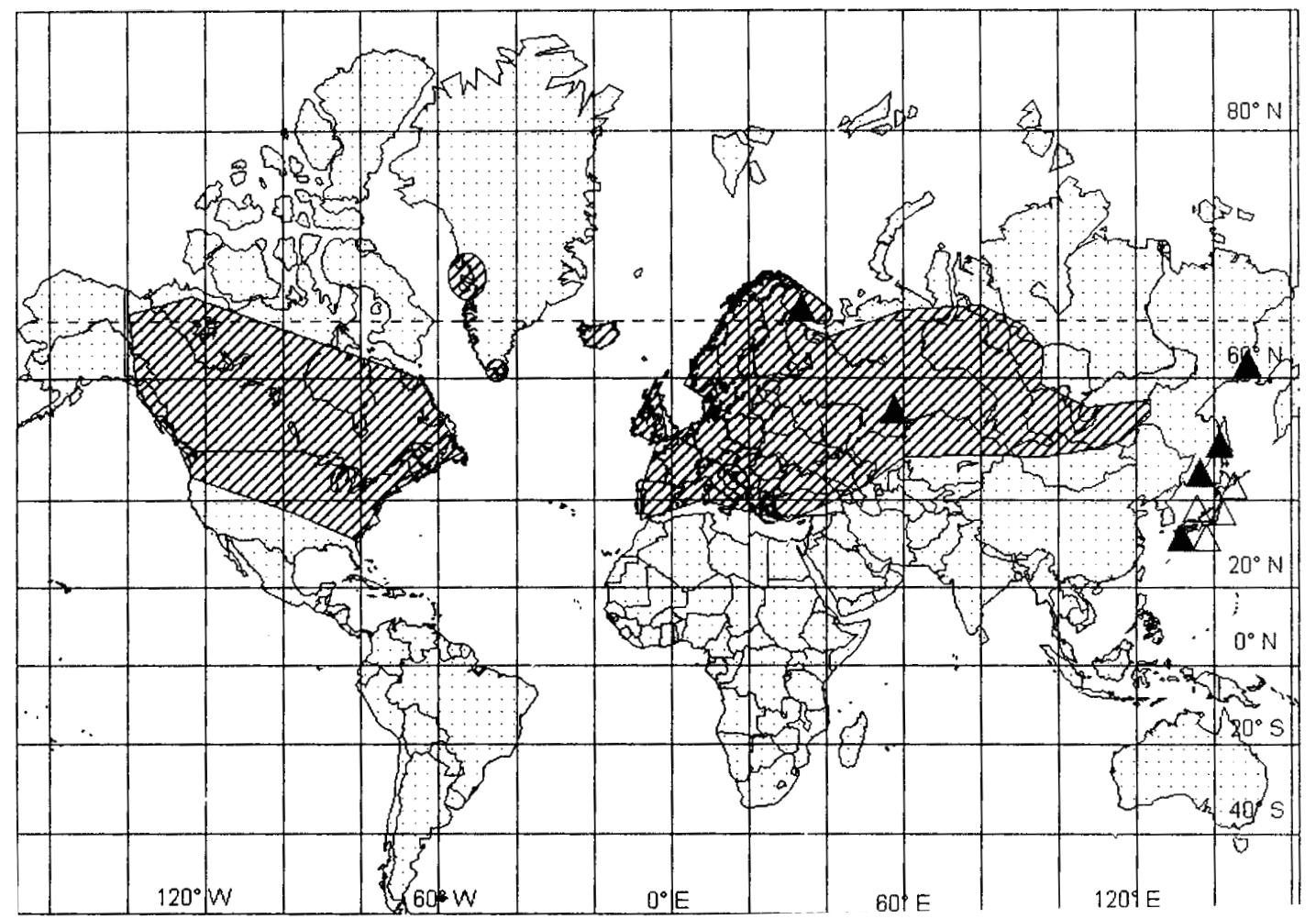

Fig. 8. The distribution of L. silvicoloides Kitag.: solid triangles - specimens examined, open triangles - literature records, and L. silvicola Buch: hatched area.

The analysis of species' distribution has shown that $L$. ventricosa is not vicarious with L. silvicoloides, and the two taxa have partly coinciding areas (Fig. 8).

Specimens of $L$. silvicoloides examined: RUSSIA: Murmansk Province. Murmansk, vallis Ujutaensis, leg. V.A. Bakalin 22.X.99. (KPABG, duplicate in KYO). South Ural. Bashkiria, Beloretzk Distr. leg. E.A. Ignatova 31.IX.90. (MHA). Magadan Province. Kolyma Riv., Kulu settl. leg. L.S. Balagodatskikh 29.VIII.79 (KPABG). Khabarovsky Kray. Sovgavansky Distr., Koppi settl. leg. Lebedinskaya IX.70. (KPABG). Primorsky Kray. Partizansky Distr. Olkhovaya Mt. leg. S.K. Gambaryan 1993. (KPABG). JAPAN: Honshu. Pref. Gifu, near Shino-Ike, Mt. Ontake. leg. N. Kitagawa 14.VIII.64 (KYO, holotype).

PRELIMINARY KEY TO HOLARCTIC SPECIES OF GREEN-GEMMOUS LOPHOZIAS BASED PRINCIPALLY ON EURASIAN SPECIMENS ${ }^{1}$

1. Perianth mouth lobulate with cilia more 4 cells long .................... 2

- Perianth mouth not lobulate or plants sterile ............................. 5

\footnotetext{
1 - Lophozia subapiculata Schust. et Damsh. is treated here as a synonym of L. ventricosa, although the former may deserve the status of a separate variety of the later.
}

2. Lobules of perianth's mouth sparse, unistratose cilia usually not more 2(3) cells long, the last cell of cilia to $2 \mathrm{x}$ as long as wide, plants of moist habitats with concave to cupped symmetrical leaves, usually no red or purple pigmentation of the shoots . . L. wenzelii

- Leaves not concave, (or cupped, but then they are strongly dorsally secund with acute lobes and with dense rhizoids mats $-L$. lacerata) frequently with red or purple pigmentation .......................... 3

3. Sinus descending to $1 / 3-1 / 2$ of leaf length, leaves decurved from the stem, symmetrical, oilbodies nonbiconcentric, shoots peculiarly straw-greenish pigmented, as a rule with numerous ascending gemmi parous shoots with undifferentiated ventral merophyte; ventral segment of the stem is the same colour with dorsal one, rare (mod. leptoderma) brownish to brown without any trace of red or purple pigmentation ............. ascendens

- Sinus descending to $1 / 3$ of the leaf length, leaves asymmetrical, oilbodies biconcentric or nonbiconcentric, ascending shoots uniform- 
ly absent, ventral merophyte differentiated, ventral segment usually purple-brown pigmented ........................... 4

4. Leaves decurved from the stem, oilbodies biconcentric, bracteole present . . L. silvicoloides

- Leaves cupped, oilbodies nonbiconcentric, bracteole absent . . . . . . . . . L. lacerata

5. Leaves concave (not conduplicate!) to cupped, without funnelate base; width of the leaf nearly equal to the leaf length, sinus crescentic, rare angulate . .......... 6

- Leaves explanate, decurved from the stem or conduplicate, the base of the leaf usually clasping the stem, leaf width considerably less then its length, rarely more or less equal . . . 10

6. Leaves very polymorphous: bilobed, with a prominent tooth of antical margin and irregularly 3(4)-lobed; perianths and ends of lobes frequently violet pigmented . . L. heteromorpha

- Leaves not polymorphous, bilobed, rarely trilobed; no violet pigmentation . . . . . . . 7

7. Leaves strongly dorsally secund, almost transversely inserted, rhizoids in dense mat, lobes acute ............. L. lacerata

- Leaves symmetrical or subsymmetrical, lobes obtuse, rare (L. savicziae) acutish, but then cells in the midleaf exceeding $30 \mathrm{mmm}$ width; rhizoids moderate to sparse . . . . 8

8. Width of the cells in midleaf exceeding 30 $\mu \mathrm{m}$; oilbodies (15) 20-50 per cell, at least $50 \%$ biconcentric; leaves obliquely inserted, gemmae 5- to polygonal, shoots usually peculiarly orange-brown coloured . . . . . . . L. savicziae

- Width of cells in midleaf not exceeding 30 $\mu \mathrm{m}$; oilbodies up to $15(20)$ per cell, biconcentric or non-biconcentric, leaves moderately oblique to almost subhorizontally inserted, gemmae 3--4(5)-angular . . . . . . . . . 9 9

9. Oilbodies biconcentric, leaf cells usually with convex to large trigones; leaves slightly asymmetrical to almost symmetrical, almost subhorizontally inserted, gemmae triangular to quadrangular ........... L. schusteriana

- Oilbodies nonbiconcentric, cells usually with only small trigones, leaves more or less symmetrical, slightly oblique to almost transversely inserted, gemmae quadrangular rarer pentangular ........... L. wenzelii s.l.
10. Base of the leaf clinging the stem, leaves conduplicate, lobes directed to the apex and forming "capitate" top of shoot, trigones usually convex to gibbous, cell lumen peculiarly decurved, oilbodies nonbiconcentric, trilobate leaves lacking crescentic sinuses, gemmae early deciduous and concentrated on the apex of the shoots, sinus of bracts incurved from the perianth .... L. ventricosa

- Funnelate base almost uniformly absent, leaves not conduplicate, deflected from the stem, not forming "capitate" top, trigones small to moderate, rare bulging, cell lumen not decurved, oilbodies biconcentric or nonbiconcentric, trilobate leaves with crescentic sinus present almost always, sinus of the bracts not inflected . . . . . . . . . . . . . . 11

11. Oilbodies biconcentric, sinus descending to 1/ 4 of the leaf length, leaves asymmetrical, shoots bright green to green-brownish and red brown, creeping, ventral segment clearly differentiated from the dorsal one, commonly brown to red or purple, perianth mouth with 1-2 celled teeth .................... L. silvicola

- Oilbodies nonbiconcentric, sinus descending to $1 / 3$-- 1 / 2 of leaf length, leaves symmetrical, shoots peculiarly straw-greenish coloured, usually with numerous ascending gemmi parous shoots, ventral segment with the same pigmentation as the dorsal one, or brownish to brown (mod. leptoderma), without any red or purple traces, perianth mouth lobulate with cilia of up to 9 cells, obligate epixylous species .......... L. ascendens

\section{ACKNOWLEDGMENTS}

I thank the curators of BM, KYO, LE, MHA, MUB, MW, NMW, PMAE, PZV, STR, SYKO, and UPS for the loan of Lophozia specimens. I am grateful to Prof. N. A. Konstantinova and Prof. J. Vana for helpful discussing some lophozioid problems. The electronic version of the distribution's map was kindly compiled by Mr. A. N. Savchenko. In addition, I am very grateful to Dr A. R. Perry for correcting the English in the manuscript. This work was partly supported by the Russian Foundation for Basic Researches, grant 00-04-48874 and 0104-06395. 


\section{LITERATURE CITED}

BAKALIN, V.A. 2000. Notes on Lophozia I. What is Lophozia silvicola Bush var. grandiretis Buch et S. Arnell. - Arctoa. 9: 111-114.

BUCH, H. 1933. Lophozia silvicola Buch sp. nov. - Ann. Bryol. 6: 125-129.

BUCH, H. 1936. Suomen Maksasammalet. - Helsinki, 116 pp.

DAMSHOLT, K. 1994. On the identity of Jungermannia groenlandica Nees. - J. Hattori Bot. Lab. 75: 173-178.

DICKSON, J. 1790. Fasciculus Secundus Plantarum Cryptogamicarum Britanniae. - London, 31.

DILlENIUS, J.J. 1741. Historia Muscorum. - Oxonii. [republication: 1811. Edinburgi], xxi +576 .

DU MORTIER, B.C. 1875. Hepaticae Europae. - Bull. Soc. Bot. Belg. 13: 1-203.

GOTTSCHE, C.M., J.B.G. LINDENBERG \& C.G. NEES ab ESENBECK 1844. Synopsis Hepaticarum. Hamburgi, 834.

GROLLE, R. 1976. Verzeichnis der Lebermoose Europas und benachbarter Gebeite. - Feddes Repert. 87: 171279.

GROLLE, R. 1983. Hepatics of Europe including the Azores: an annotated list of species, with synonyms from the recent literature. - J. Bryol. 12: 403-459.

GROLLE, R. \& D. G. LONG 2000. An annotated check-list of the Hepaticae and Anthocerotae of Europe and Macaronesia. - J. Bryol. 22: 103-140.

HOOKER, W. J. 1816. British Jungermanniae. - London, xxviii $+84,88$ tables.

LONG, D. G. 1979. Hepatic types of James Dickson in the Edinburg herbarium. - J. Bryol. 10: 241-244.

KITAGAWA, N. 1965. A revision of the family Lophoziaceae of Japan and Adjacent Regions. 1. - J. Hattori Bot. Lab. 28: 239-291.

MICHELI, P.A. 1729. Nova Plantarum genera. - Florentiae, 234.

MÜLLER, K. 1954. Die Lebermoose Europas. Band VI.
Auflage 3. Lieferung 5. - Leipzig, 641-756.

NEES VON ESENBECK, C. G. 1836. Naturgeschichte der deutschen Lebermoose. Vol. 2. - Berlin, 500.

PATON, J. A. 1999. The liverwort flora of the British Isles. - Colchester, 626.

SAUKEL, J. 1985. Zum Merkmalsbestang einiger Mitteleuropäischer Arten der Lebermoosgattung Lophozia (Dum.) Dum. (Sektion Lophozia). - Stapfia 14: 149-185.

[SCHLJAKOV, R. N.] ШЛЯКОВ, P. H. 1974. Новые таксоны рода Lophozia Dum. emend. Schljak. - [New taxa of genus Lophozia Dum. emend. Schljak.] Новости сист. низи. pacm. [Novosti Sist. Nizsh. Rast.] 11: 350-354.

[SCHLJAKOV, R. N.] ШЛЯКОВ, Р. Н. 1980. Печеночные мхи севера СССР. T.3. - [Liverworts and Hornworts of North of the USSR. Vol. 3.] Л., Наука [Liningrad, Nauka], 190.

[SCHLJAKOV, R. N.] ШЛЯКОВ, Р. Н. 1982. Печеночные мхи севера СССР. Т. 5. - [Liverworts and Hornworts of North of the USSR. Vol. 5.] Л., Наука [Liningrad, Nauka], 196.

SCHLJAKOV, R. N. 1998a. On the Lophozia groenlandica (Nees) Macoun. - Arctoa 7: 191-196.

[SCHLJAKOV, R.N.] ШЛЯКОВ, P.H. 1998b. Два новых таксона мохообразных с Южного Урала и Алтая. [Two new taxa of Bryophytes from South Ural and Altai] Hовости сист. низи. pacm. [Novosti Sist. Nizsh. Rast.] 32: 180-183.

SCHMIDEL, C. C. 1783. Dissertatione Botanici. -- Erlangae.

SCHUSTER, R. M. 1969. Hepaticae and Anthocerotae of North America. - New York and London, 1062

STEENSTUP, J. \& J. LANGE 1858. Flora Danica. Copenhagen 15(44): 21.

STEPHANI, F. 1902. Species Hepaticarum. Vol. II. -- Geneva, 615.

WEBER, F. 1815. Historiae Muscorum Hepaticorum Prodromus. - Kiliae, 160. 